\title{
クラフト紙の強度に関する研究*
}

\section{第2 報＼cjkstart乾燥中の張力が紙力に及ぼす影響（1）}

藤 原 行 雄 ${ }^{* *}$

\section{$\S 1$ 緒 論}

機械抄造紙の強度の異方性は, 㵶維配列と乾燥中の 収縮阻止とがその主な原因と考えられている。そして, 繊維配列は, ワイヤーパートに括ける紙層形成中に生 じ，収縮阻止は，ドライヤーパートで乾燥中に起ると 考光られる。乾燥中に紙葉に加えた張力が仕上った紙 の強度にどのような影響を与えるかという問題につい て，今日末でに多くの研笔が発表されている。しかし， これらはいずれる一方向に張力を作用させ，その方向 の抗張力, 伸度等を測定したものであり, それと直交 する方向の張力は考虑されていない。

抄紙機乾燥部で紙葉のうける作用は, マシンオ向の 㖘りとともに, カンバス及びドライヤー表面との接 触によるクロス方向の収縮阻止があるので, この点を 考虑することが必要である。

ここに述べる実験では，等方性手抄紙の縦と横の方 向に張力を加えながら乾燥させ, 各方向について紙力 の異方性がどのように発展するかを研究した。この目 的のために直交する二方向に張力を加兄得る装置を考 案した。湿紙は水平方向に支持され, 上方より電気七 一ターの輻射熱で乾燥される。乾燥時間と乾燥度の関 係を求めて物き，次に乾燥中の一定時間每に紙葉の縦 および横方向の収縮率を測定した。乾燥収縮率と紙葉 に加觉た張力とは, 非常に興味深い関係にあることが 見出された。横方向の張力を一定にして, 緃方向の張 力をいろんな大きさにした場合, 抗張力, 伸度, 破裂

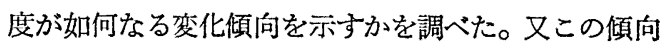
は, 横方向の張力が異る場合に, ぞのような相違があ るかについて研究した。乾燥収縮は乾燥紙の引喛試験 における伸度と密接な関係にあることが示される。第 1 報***において，著者が提出した破裂度の関係式を 適用して, 抗張力と伸度から破裂度を計算し, 実測值 と比較した。雨者の間にはかなりの差が認められるが, 全般的傾向は一致している。

* 原稿受付 31. 8. 12

** 東洋パルプ KK 只工場研究課

*** 本誌投稿中

\section{$\S 2$ 实験装置}

Fig. 1 に，この奉験に使用した装置を示した。AB 及びCDの二対のクランプで湿絓を固定し, 水平方向 に支持する。クランプで固定した部分と自由端部分と の収縮差によるしわの発生を少なくするために，眓に 示したように湿紙に切れ目を入れた。湿紙の上方約 35 $\mathrm{cm}$ の位置に, $1 \mathrm{kw}$ 電気ヒーターを下向きに固定して,
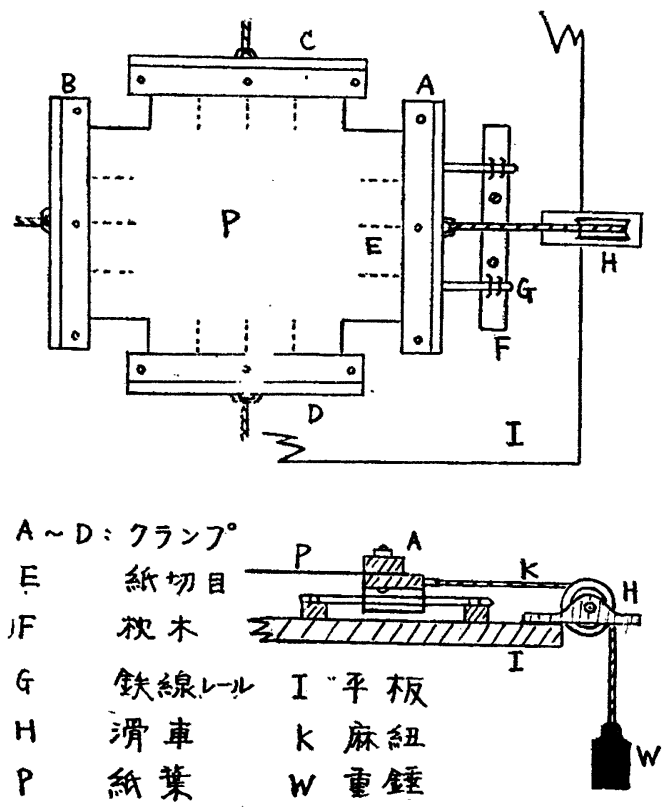

Fig：１実験装置。

上方から輻射線を照射して乾燥させた。クランプは麻 紐, 滑車, 重鍾により一定の力で弓涱られる。クラン プは紙葉の収縮伸長に応じて, 前後に自由に移動する ように鉄線レールで支持されている。実験に用いた乎 抄紙は $25 \mathrm{~cm} \times 18 \mathrm{~cm}$ の大きさで, 紙力試験に供する 部分は $12 \mathrm{~cm} \times 12 \mathrm{~cm}$ の寸法である。手抄紙は奥研式 を改造した装置を使用して，8\% 水分換算で米坪 83 $\mathrm{g} / \mathrm{m}^{2}$ になるように作成した。原料は口ーエ価 5.8 の クラフトパルプを実験用ビーターで 400 c.c まで郒 したものを用いた。絓葉の収縮率及び伸長率は次のよ 
うな簡単な方法で測定したが，精度は余り良くない。 湿紙の縱横の方向に長さ $10 \mathrm{~cm}$ の線を印しておき, 乾燥中にこの長さの変化を $1 \mathrm{~mm}$ 目盛の物差しで 0.2 $\mathrm{mm}$ まで読み取った。一定の乾燥条件について四枚の 紙葉を乾燥させ, 二枚を破裂度試験に，残りの二枚を 各々, 縦方向々横方向の引張試験に供した。測定回数 はいずれも 6 回である。

\section{$\S 3$ ，乾燥度と乾燥収縮率との関係}

Fig. 2 に乾燥時間と紙葉水分の関係を示した。これ は圧力 50 p.s.i. 時間 10分のプレスにより， 水分約 $70 \%$ になった 紙 紙葉を一定時間乾燥さ，舟的 せ, 前後の重量变化捄 よび絶乾重量を天种で 測定して求めたもので ある。Fig. 3 は紙葉に $10 \mathrm{~g} / \mathrm{cm}$ の張力を加兄 て乾燥させた時の乾燥 時間と乾燥収縮率との 関係である。この程度 の張力は紙葉を平面に 保つための最少限度の 大きさで, 自由收縮の 場合とほとんど同一と みなせる。

以上二つの関係から 乾燥度と収縮率との関 係を求めると Fig. 4 が得られた。收縮は水 分 $65 \%$ 付近飞始まり 水分 $10 \%$ 付近にいた るまで，ほぼ直線的に

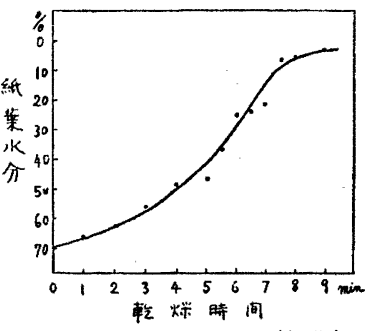

Fig. 2 乾丵時问一乾棪度

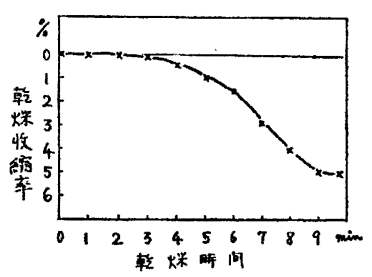

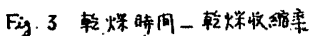

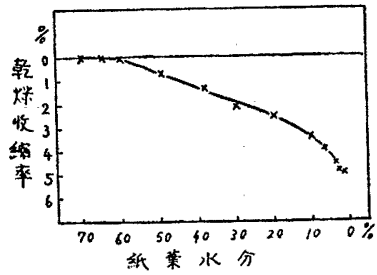

Fig 4 畭熑度一畭粪收统率。
$3.5 \%$ 収縮している。水分 $10 \%$ 以後の急激な収縮は 乾燥過度による紙葉のコックリングによるるのである。

\section{$\S 4$ 乾燥中の張力と乾燥収縮率との関係}

横方向の張力を $10 \mathrm{~g} / \mathrm{cm}$ とし, 縦方向の張力をそ れぞれ $10 \mathrm{~g} / \mathrm{cm}, 50 \mathrm{~g} / \mathrm{cm}, 100 \mathrm{~g} / \mathrm{cm}$ ，とした場合の， 各方向の収縮率と乾燥度の関係を Fig. 5 に示した。 張力による縦櫝の収縮差は湿紙に張力を加充た時すで 飞発生して敊り，乾燥中にさらに収縮差は増大する。 縦方向の張力を大きくすると，この方向の収縮は減少 乙, 横方向の収縮は增大する。張力と収縮の関係を広 い範四について測定し，Fig. 6 のような関倸が得られ

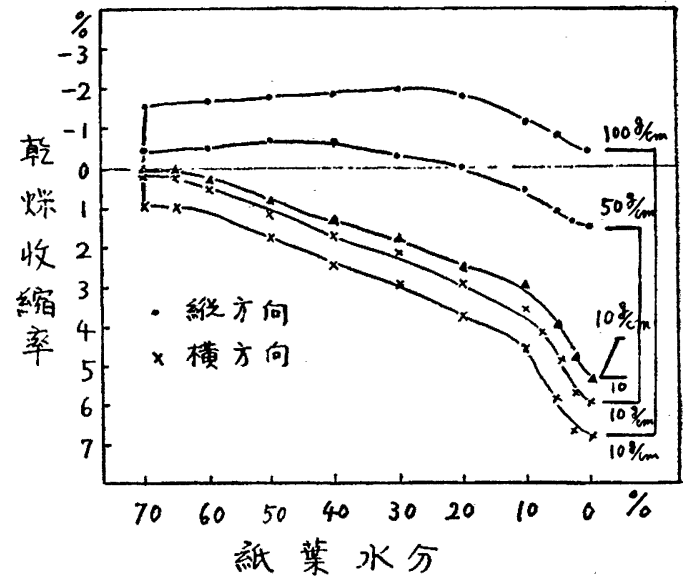

F 5 張力火小る縱横の乾棪收缩差。

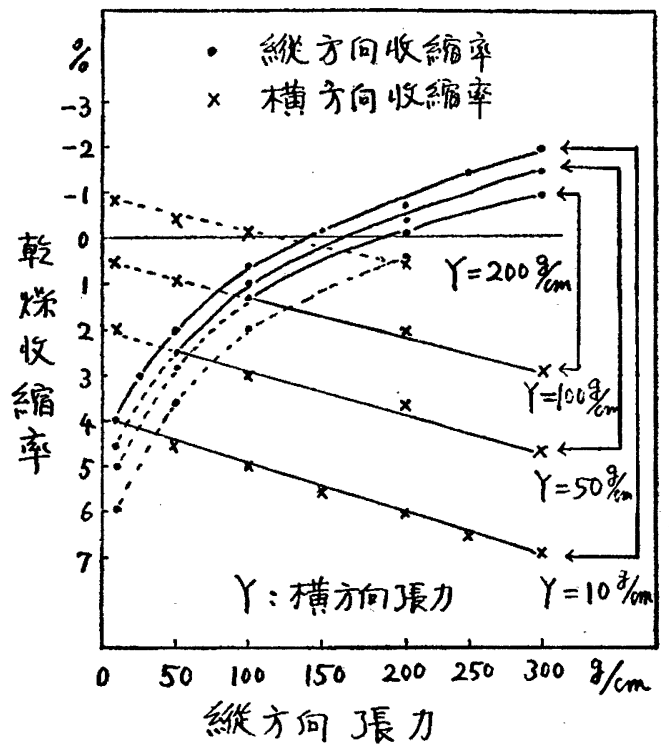

Fig. 6 乾䐆中の張力长乾棪收縮。

た。図に扣いて，横軸は乾燥中の縦方向の張力をとり， 縦軸比は乾燥終了時の紙葉の収縮率が目盛ってある。 横方向の張力が $10 \mathrm{~g} / \mathrm{cm}, \quad 50 \mathrm{~g} / \mathrm{cm}, 100 \mathrm{~g} / \mathrm{cm} .200$ $\mathrm{g} / \mathrm{cm}$ の場合に対して, 縦方向に $10 \mathrm{~g} / \mathrm{cm}$ から 300 $\mathrm{g} / \mathrm{cm}$ までの範囲のいろんな張力を加えた時の各方向 の乾燥収縮率を示す曲線が示されている。ここで縦方 向と横方向を指定したが，紙薬は最初は全く等方性で あるから，縱横は張力に関して相対的意味をるつたけ である。したがって，例えば横方向の張力が $50 \mathrm{~g} / \mathrm{cm}$ で縱方向張力が $100 \mathrm{~g} / \mathrm{cm}$ の場合の綎方向の収縮率は, 横方向の張力が $100 \mathrm{~g} / \mathrm{cm}$ で, 縦方向張力 $50 \mathrm{~g} / \mathrm{cm}$ の 場合の横方向の収縮率と同等である。このような考它 
にしたがって，図表上の点を拡張していくと，Fig. 6

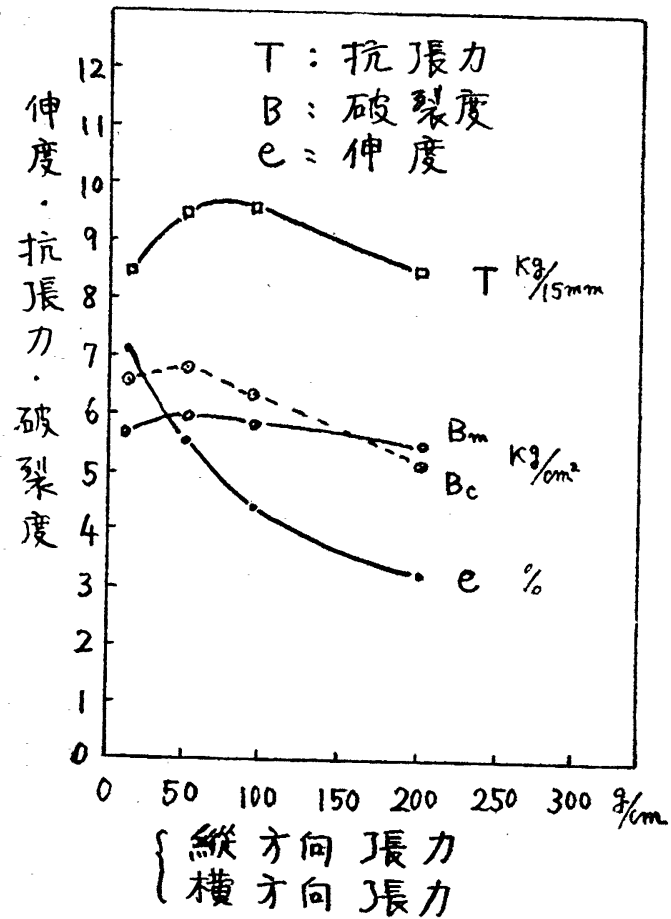

Fig 7 張力と紙力の囘係

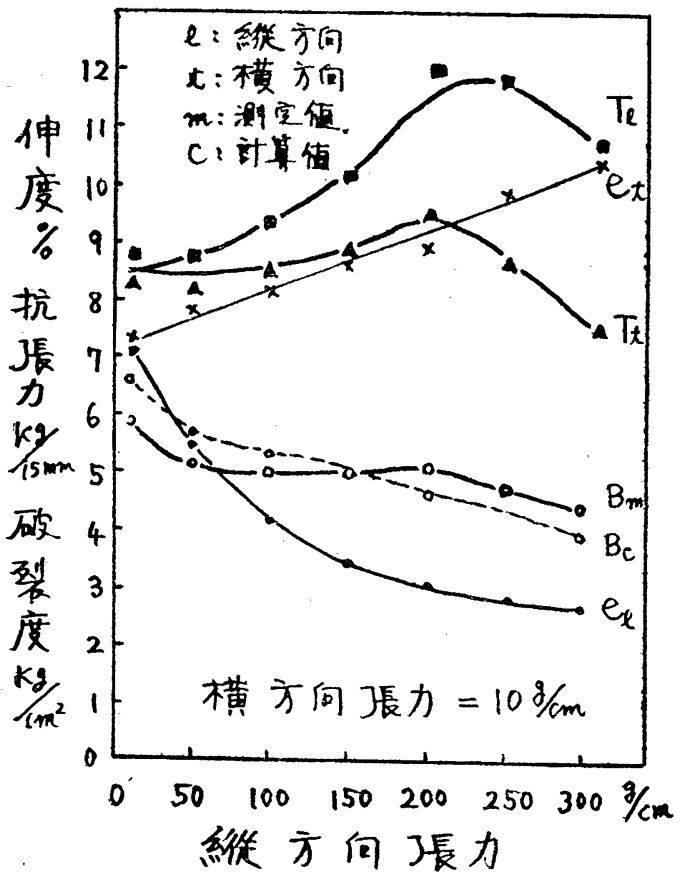

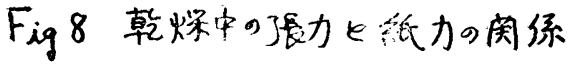

のような直線群と曲線群が得られる。図において，実 線部分は実測值に基づいて画いたもので, 破線部分は

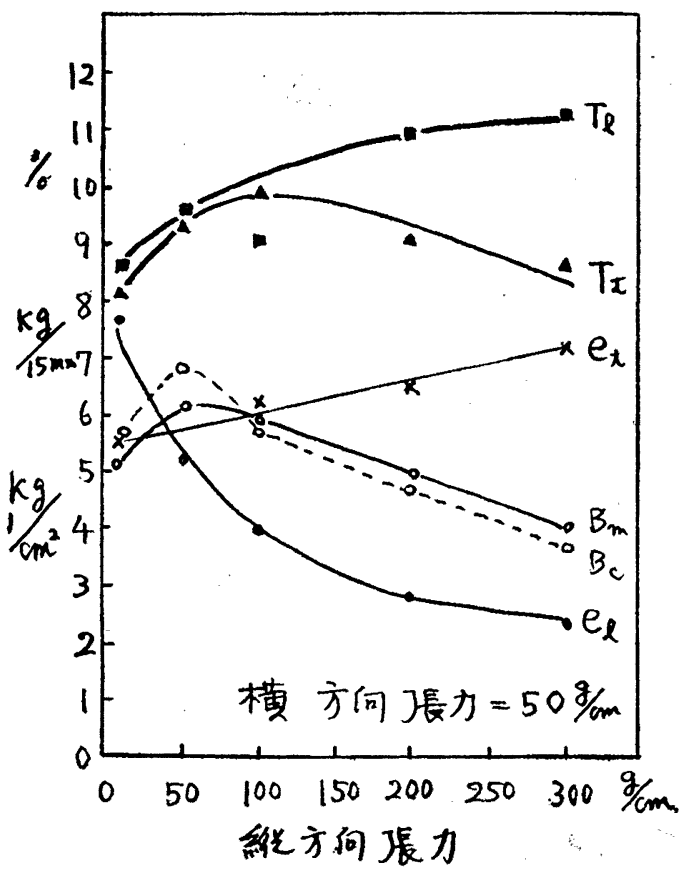

Fig 9 張力上紙力の肉绿

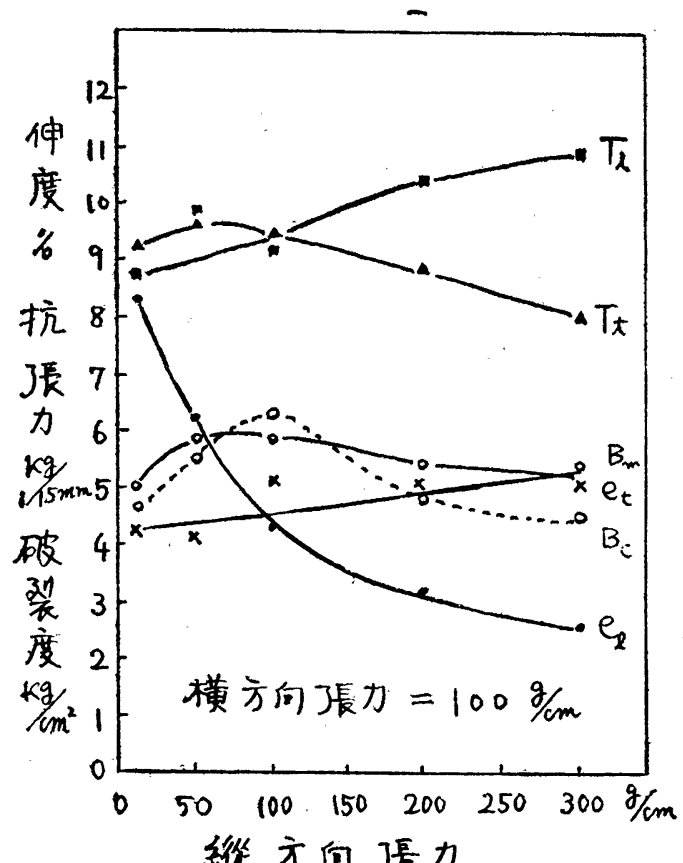

Fig.10 乾樮中9張力と衹力 
上述の方法で補足した点にもとづき画いたるのである。 これら二曲線群は相互に同等であり, 標示方法が買っ ているだけである。張力と収縮との関係の著しい特徵 は, 緃方向の張力の增大に応じて, 同方向の収縮は曲 線的減少し，横方向の収縮は直線的飞增大している ことである。

\section{$\S 5$ 乾煤中の張力と紙カとの関係}

張力を絽横同一とし, $10 \mathrm{~g} / \mathrm{cm}$ から $200 \mathrm{~g} / \mathrm{cm}$ の大 きさの範围に対して, 張力に応じて紙力がどのように 変化するかを Fig. 7 に示した。破裂度と抗張度は最 初やや增大し, 後張力の增大によって減少する。伸度 の減少は著しい。次横方向の張力を $10 \mathrm{~g} / \mathrm{cm}, 50$ $\mathrm{g} / \mathrm{cm}, 100 \mathrm{~g} / \mathrm{cm}, 200 \mathrm{~g} / \mathrm{cm}$ とした場合の各々に対し て, 縦方向の大きさに応じて紙力がどのように変るか を調べた。Fig. 8〜Fig. 11 に結果を示す。Fig. 8 に

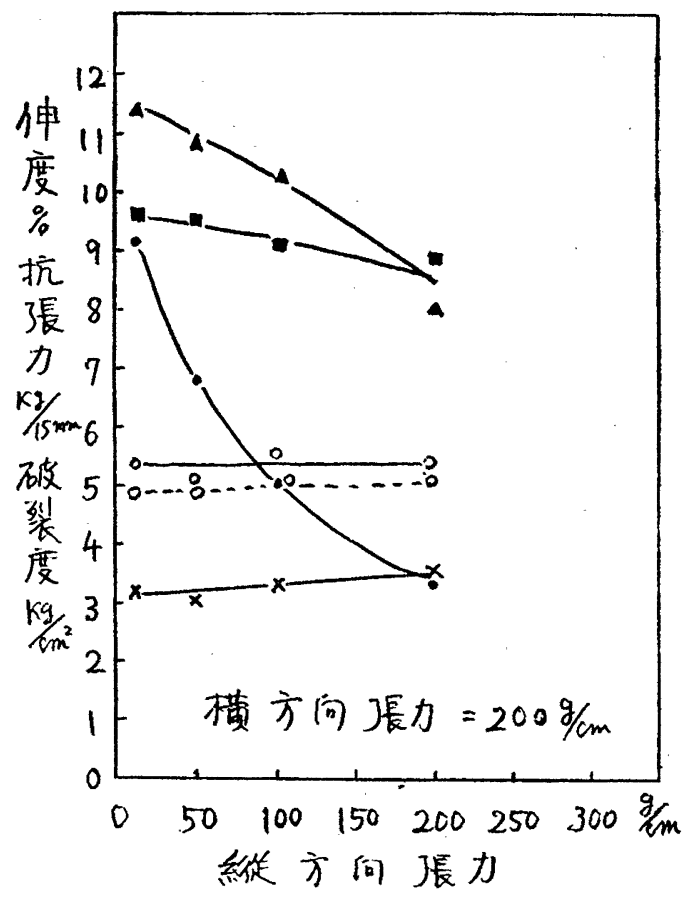

\section{Fig.11乾䐆中の張力と紙力}

よれば, 横方向の張力 $10 \mathrm{~g} / \mathrm{cm}$ の時, 䋡横の抗張力 は, 緃方向の張力 $200 \mathrm{~g} / \mathrm{cm}$ までは雨者とも次第に增 大し，それ以上ではやや急激に減少している。緃方向 の伸度は張力によって曲線的に隇少するが, 横方向の 伸度は值線的に増大している。この傾向は乾燥収縮の 張力に対する傾向と非常に類似して括り, 雨者の閒の 密接な関係を暗示している。破裂度は縦方向の伸度の 減少々より，最初は僅かだけ減少するが，抗張力の増
大で補われて, 張力 $200 \mathrm{~g} / \mathrm{cm}$ まではほとんぞ一定に 保たれる。張力がさらに增すと抗張力の減少により破 裂度も減少する。四に招いて破線で示した曲線は, 著 者が第 I 報で提出した関係式を用いて，抗張度と伸度 より計算した破裂度予測值にもとづき画いたものであ る。

Fig. 9 は横方向の張力を $50 \mathrm{~g} / \mathrm{cm}$ とした場合で, Fig. 8 と比較すると, 著しい相違が認められる。この 場合, 縦方向の張力が $50 \mathrm{~g} / \mathrm{cm}$ の時, 絽横の張力が 一致し, 紙葉は等方性となっている゚ 綎方向の抗張力 は張力の增大につれて大きくなり，Fig. 8 の場合には 減少の傾向があらわれた $250 \mathrm{~g} / \mathrm{cm}$ になってる，依然 として增大している。これに対し横方向の抗張力は, 張力 $100 \mathrm{~g} / \mathrm{cm}$ ですでに隇少の傾向を生じている。 Fig. 10 は横方向の張力 $100 \mathrm{~g} / \mathrm{cm}$ の場合で, 紙力の 变化傾向は Fig. 9 と根本的な相違はみられない。 Fig. 8 から Fig. 11 までのいずれについてる, 伸度 の張力に対する変化傾向は榦燥収縮のとれと類似して いる。しかし，収縮率と伸度とは量的には一致してい ない。この点に関しては後に詳しく考察する(第 3 報* 参照)

乾燥中の張力により，抗張力が堌大する理由汇つい ては, 決定的なことはわからないが大体次のように推 定される。湿紙中の可塑性をるった瀻維は張力の加っ た緊張状態の紙葉中で，ポテンシャルエネルギーがな るべく低い安定状態に配列する傾向がある。即ら䄉維 は張力方向に向きを変えたり，屈曲䋐維が伸長したり， 䋐維間の空陧が詰ったりする。これは結果的沉は，緎 維全体として僅かながら張力の大なる方向に配位し, 䋐維間接触は增大する。縱横の抗張力がともに增大す るのはこのためと考えられる。又繊維が張力の大なる 方向に, ある程度配位することは, 張力の大なる方向 の抗張力を，より大きくする。張力がある限度をこえ ると, 緎維間の絡み合によって湿紙は破壊に到らず張 力に耐兄うるが，繊維間には空嚐が生じてくる。これ は大きな張力を加兊た時, 湿紙が空気を含んで白色を 帯びてくることより推定される。その結果として, 抗 張力は減少する。以上は, 湿紙中の張力の作用たけに ついて考党たのであるが, 乾燥中の各段階に和ける張 力の影響を考虑することが必要である。このためには 張力の条件を変えて実験を行わねばならない。

\section{$\S 6$ 結論}

等方性手抄紙の縦拉よび横方向に張力を作用させて 乾燥させると，紙力は次のような結果となった。

* 本誌投樀中 
1）横方向の張力が比較的小なる場合，緃方向の張 力の增大とともに, 縱横の抗張力は增大する。張力が 一定限度をこえると，抗張力は縱横ともに減少する。

2）棤方向の張力が比較的大なる場合，縦方向の張 力の增大に上り, 同方向の抗張力は增大する。これに 対し, 横方向の抗張力は最初僅か飞增大して後, 減少 する。

3）乾燥収縮と伸度とは, 乾燥中の張力に対して, 類似した变化傾向を示す。即ち縦方向の張力增加に対 して, 収繀率又は伸度は, 縦方向では急激に曲線的に 減少し，横方向では直線的に增大する。

4) 破裂度の变化傾向は, 抗張度と伸度により定っ てくる。これと対して, 著者が第 1 報で提出した関係 式が近似的に成立する。
以上の結果は，乾燥中の張力が始終一定に保たれた 場合に得られたるのである。したがって，これだけか ら機械抄造紙が乾燥部でうける作用と，その結果とし て生ずる紙力の傾向との関連を求めることは無理であ り,さらに多くの実験結果の蓄積を待たねばならない。

\section{交献}

1) Walter Brecht, Dieter Pothman Das Papier 9 304 (1955)

2) H. F. Rance TAPPI 37640 (1954)

3) H. F. Rance "Mechanical Properties of Wood and Paper" Amstcrdam North Holland Publishing Co. (1953)

4) S. F. Smith T.S. of B.P. \& R.M.A. 31 Part I (1950)

\section{Studies on the Strength of Kraft Paper \\ Report 2 Influence of the Tension during Drying upon the mechanical Properties of the Paper Sheet (1) \\ Yukio Fujiwara.}

Isotropic wet handsheets were dried by radiation of electric heater under various tensions, and behaviors of the paper sheets were investgated. Handsheets were made from kraft pulp of Roe No. 5.8, beaten to a Canadian freeness of $400 \mathrm{cc}$. The hasis weight of the dried sheets was $83 \mathrm{~g} / \mathrm{m}^{2}$ at $8 \%$ moisture content.

Results obtained by the experiment are as follows:

1) When tension of the wet sheet in the transversal direction is fixed at $10 \mathrm{~g} / \mathrm{cm}$ and tension in the longitudinal direction is set various values in the range of $10 \mathrm{~g} / \mathrm{cm}$ to $300 \mathrm{~g} / \mathrm{cm}$, tensile strength of the both directions becomes larger with increase of the longitudinal tension to $250 \mathrm{~g} / \mathrm{cm}$, above which they decrease somewhat rapidly (See Fig. 8)

2) When the transversal tension is fixed at $50 \mathrm{~g} / \mathrm{cm}$ or $100 \mathrm{~g} / \mathrm{cm}$, tensile strength in the transversal direction decreases at the lower value of the longitudinal tension, but longitudinal tensile strength increases in the whole range of longitudinal tensile strength increases in the whole range of longitudinal tension. (See Fig. 9, Fig. 10)

3) Breaking elongation in the longitudinal direction becomes smaller remarkably as the tension of the same direction increases, while elongation in the transversal direction becomes larger linearly. (See Fig. $8 \sim$ Fig. 10)

4) The tendency of dry shrinkage for the increase of tension is analogous with that of the breaking elongation, which appears to suggest a close relationship between breaking elongation and dry shrinkage (See Fig. 6 and Fig. $8 \sim$ Fig. 11)

5) Bursting strengths, calculated by the formula which the auther has given in the preceding paper, are represented by dotted lines in Fig. $7 \sim$ Fig. 11 . Calculated values have almost the same tendency for the increase of tension as that of the measured values. 